\title{
FILMSKA INDUSTRIJA KAO PROMOTOR TURISTIČKE DESTINACIJE ZA MLAĐU POPULACIJU ${ }^{4}$
}

\section{SAŽETAK}

Filmski turizam postaje sve popularniji na globalnom turističkom tržǐ̌tu, konkurencija među destinacijama domaćinima sve je veća, pa se ulažu veliki napori u privlačenju filmskih setova, a filmski lokaliteti odigravaju značajnu ulogu u planiranju marketinških aktivnosti turističkih destinacija. Ovim radom nastoji se istražiti utjecaj gledanja filmova na odluku o odabiru turističke destinacije kod mlađe populacije. Postavljene su hipoteze koje pretpostavljaju da filmovi utječu na odluku ispitanika prilikom odabira turističke destinacije te da je filmska priča presudna u odabiru destinacije prikazane u filmu. U cilju dokazivanja postavljenih hipoteza provedeno je kvantitativno istraživanje. Ispitanici su odgovarali na pitanja koja se odnose na njihove navike gledanja filmova, navike i preferencije tijekom putovanja, želje i potrebe prilikom izbora turističke destinacije viđene u filmu, na informacije o već ostvarenim putovanjima u svrhu posjeta filmskim destinacijama i događajima, te na pitanja koja se odnose na njihove želje i buduće namjere prilikom odabira turističke destinacije. Podaci su analizirani primjenom metoda deskriptivne i induktivne statistike, hipoteze su testirane i doneseni su zaključci o povezanosti primjenom izračuna hi-kvadrat testa. Rezultati istraživanja pokazali su značajnu povezanost učestalosti gledanja filmova ispitanika s njihovom odlukom o odabiru turističke destinacije, a kao poticaji za posjet destinaciji pokazali su se ljepota krajolika, specifične lokacije iz filma i kulturno-povijesne znamenitosti. Istraživanje je provedeno na prigodnom uzorku, pa interpretaciju i generalizaciju rezultata treba uzeti u obzir s dozom opreza. Sobzirom na porast broja međunarodnih filmskih produkcija tijekom posljednjih godina, filmski turizam u Hrvatskoj bilježi značajan rast pa rezultati ovog istraživanja mogu poslužiti kao putokaz za planiranje marketinških aktivnosti i brendiranje Hrvatske kao filmske destinacije.

Ključne riječi:filmski turizam, motivi putovanja, marketing destinacije, odabir destinacije, ponašanje potrošača

\section{UVOD}

Globalno, zbog sveprisutne popularnosti i komunikacijskih dosega filmova, a samim time i lokacija na kojima su snimljeni, razvio se posebni oblik turizma poznat kao filmski turizam ili filmski inducirani turizam. Ovaj oblik turizma spada u kulturni turizam, koji se smatra svjetskim fenomenom koji potiče ekspanziju kulturnih sadržaja, razvoj industrije zabave i porast broja

\footnotetext{
Dr. sc., docent, Fakultet za menadžment u turizmu i ugostiteljstvu, Primorska 42, 51410 Opatija, Hrvatska. E-mail: lidijab@fthm.hr

2 Mag. oec., student, Fakultet za menadžment u turizmu i ugostiteljstvu, Primorska 42, 51410 Opatija, Hrvatska.

3 Mag. oec., Centar za studije i studente Sveučilišta u Rijeci, Radmile Matejčić 2, 51000 Rijeka, Hrvatska.

E-mail:dmestrovic@uniri.hr

4 Datum primitka rada: 15. 1. 2018.; datum prihvaćanja rada: 1. 3. 2018.
} 
međunarodnih putovanja (Hudson, Ritchie, 2006; Wang, Gil, 2011; Pike \& Page 2014; Gartner, 2014; Beeton, 2016). Kao dio kreativne industrije, industrije zabave, umjetničkog izraza, kulture i lokalne tradicije, film koji pokreće turizam može se nazvati i dijelom kulturne turističke baštine (McKercher, Du Cros, 2002; Jewell, McKinnon, 2008; Shani, Wang, Hudson, Gil, 2009; Hudson, Wang, Gil, 2011).

Filmski turizam može poslužiti kao velika prednost nad konvencionalnim marketinškim aktivnostima pomoću kojih se turisti privlače u destinaciju. Filmski sadržaji prikazuju univerzalne priče koje za publiku predstavljaju svojevrsni bijeg od stvarnosti. Nerijetko se publika poveže s pričom na emocionalnoj razini, što se zatim odražava na njihove preferencije u odabiru njihove sljedeće turističke destinacije. Filmske lokacije pridonose popularnosti destinacije, ali nisu jedini odlučujući čimbenik za odluku o putovanju.

Određivanje utjecaja filma kao medija na ponašanje posjetitelja prilikom odabira turističke destinacije iznimno je kompleksno i zahtjevno, stoga je provedeno empirijsko istraživanje kojim bi se stekao bolji uvid u navedenu problematiku. Svrha ovog rada je istražiti povezanost gledanja filmova s ponašanjem posjetitelja prilikom odabira turističke destinacije i utvrditi koji poticaji imaju najviši doprinos u procesu donošenja odluke o odabiru. Nastavno, postavljene su sljedeće hipoteze:

- H1: Filmovi utječu na odluku posjetitelja prilikom odabira turističke destinacije

- H2: Filmska priča presudni je poticaj odabiru destinacije prikazane u filmu.

Rad se sastoji od pet cjelina, a sam uvod donosi predmet, svrhu istraživanja te radne hipoteze. Drugi dio iznosi kratak pregled literature, dok treći opisuje metodologiju i uzorak kvantitativnog istraživanja provedenog $s$ ciljem stjecanja uvida u poticaje koji pridonose procesu donošenja odluke prilikom odabira turističke destinacije i u povezanost učestalosti gledanja filmova ispitanika s njihovim namjerama ponašanja prilikom odabira turističke destinacije. Četvrtim dijelom izneseni su rezultati istraživanja dobiveni primjenom metoda deskriptivne i induktivne statistike, predložene hipoteze su testirane i doneseni su zaključci o povezanosti primjenom izračuna hi-kvadrat testa, uz kratku diskusiju, navedena su ograničenja i smjernice budućih istraživanja. Zaključkom su iznesena mišljenja autora o dobivenim rezultatima i očitovanja o polaznim hipotezama.

\section{PREGLED LITERATURE}

\section{1 Filmski turizam}

Filmski turizam svojevrsni je fenomen koji podrazumijeva putovanja u destinacije u kojima su snimane atraktivne i omiljene filmske priče posjetitelja. Filmski inducirani turizam Evans (1997) opisuje kao posjet turista nekoj destinaciji ili atrakciji koji rezultira kao posljedica njena pojavljivanja na televiziji ili kino-platnu. Filmske destinacije ostvaruju koristi kroz filmski turizam ako je sama destinacija poslužila kao lokacija snimanja ili je bila dijelom filmske priče (Skoko, 2014).

Prema Morganu i Pritchardu (1998) plasiranje turističke destinacije na TV-ekrane obilježje je prikrivenog oglašavanja. Prikriveno oglašavanje može se ukratko definirati kao uključivanje marke, 
tj. destinacije u masovne medije. Ono što je zanimljivo je to da promocija marke, u ovom slučaju destinacije, nije jasno naznačena. Marketinški stručnjaci ističu da je prikriveno oglašavanje puno sofisticiranije i učinkovitije od konvencionalnih oblika oglašavanja. Baš kao prikrivena promocija proizvoda i usluga, na malim ekranima sve se više ističu lokacije, odnosno destinacije u kojima su snimane kultne scene iz filmova. Upravo okruženje omiljenih filmskih junaka utječe na gledatelje u odabiru sljedeće turističke destinacije (Bolan, Williams, 2008). Filmska industrija inicijalno nema intenciju kreiranja i jačanja imidža turističke destinacije ili njezine promocije, no zbog same snage filmske industrije njezini učinci mogu imati izuzetno snažne razmjere ako se njima strateški upravlja. Bolan (2009) ističe veći broj ključnih točaka kojima filmska industrija pridonosi brendiranju turističke destinacije, a koje se ogledaju u većem priznanju i prihvaćanju filmskog turizma, bližoj suradnji između turističkih i filmskih organizacija, većim naporima za razvitak i promicanje filmske lokacije kao priče koja će obilježiti destinaciju, održavanju destinacije autentičnom u promotivnim aktivnostima i što sličnijom onoj koja je bila prikazana u filmu te većoj upotrebi kvalitativnih istraživanja. Hudson i Brent Ritchie (2006) navode četiri kategorije marketinških aktivnosti u kojima destinacije mogu sudjelovati u promicanju filmskog turizma: proaktivni napori za poticanje proizvođača i studija za snimanje filma na priželjkivanoj destinaciji, nastojanje stvaranja medijskog publiciteta oko filma i njegove destinacije snimanja, marketinške aktivnosti koje promiču lokaciju filma nakon završetka samog snimanja te rubne marketinške aktivnosti koje stvaraju polugu potencijala filmskog turizma.

Macionis (2004) filmske turiste - turiste koji posjećuju filmske destinacije - kategorizira u tri skupine i razlikuje: slučajne filmske turiste koji se slučajno nađu na lokacijama prikazanim u filmovima, opće filmske turiste koji nisu privučeni u filmsku destinaciju, ali su sudjelovali u različitim filmskim turističkim aktivnostima i specifične filmske turiste koji redovito traže destinacije koje su vidjeli u filmu. Slično, Hudson i Brent Ritchie (2006) svrstavaju filmske turiste u tri skupine turista koji su motivirani filmom: generalne turiste kojima primarni motiv nije bio posjet destinaciji zbog filma, no film ih je potakao u odluci da posjete tu destinaciju, specifične turiste kojima je primarni motiv posjeta destinaciji bio upravo film i slučajne turiste čiji primarni motiv nije posjet filmskoj destinaciji već su imali druge prioritete, no budući da su se iz drugih razloga našli u nekoj turističkoj destinaciji, odlučit će se i za posjet filmskim lokacijama.

\subsection{Uloga filmske industrije u marketingu turističke destinacije}

Film ima ulogu kontinuiranog poticatelja na dolazak turista u destinaciju, svojevrsni je oblik audiovizualnog komuniciranja određenih ideja, vrijednosti, poruka i značenja, pa s lakoćom može kreirati smisao destinacije na način koji će dovesti do njenog daljnjeg rasta i razvoja. Stoga je evidentno koliko značajan utjecaj mogu imati filmske produkcije na neke destinacije, a koji se ogleda kroz povećanje broja turističkih posjeta destinaciji prikazanoj u filmu (O'Connor, Flanangan, Gilbert, 2010).

Atraktivnost filmskih lokacija za posjetitelje kao novog tipa turističke destinacije zagovaraju brojni marketinški stručnjaci i znanstvenici koji se bave istraživanjem odnosa između filma i turizma. Tako Woodward (2000) ističe mogućnosti marketinga turističke destinacije, odnosno, o aktivnosti koje marketinški stručnjaci destinacije mogu poduzeti i prije samog snimanja filma, a koje 
generiranju ekonomske koristi za destinaciju tijekom i nakon same projekcija filmskog ostvarenja. Međunarodna udruga za destinacijski marketing (DMAl 2016) definira marketing destinacije kao proaktivni pristup usmjeren prema ekonomskom i kulturnom razvoju destinacije, a koji uravnotežuje i integrira interese ključnih dionika: posjetitelja, pružatelja usluga i zajednice. Može se reći da je smisao suvremenog marketinga turističke destinacije optimizacija učinaka turizma i postignuća strateških ciljeva, usmjerenih ka postizanju ekonomskih ciljeva, zadovoljenju potreba i želja što šireg kruga dionika (Križman Pavlović, Živolić, 2008) te budućih naraštaja određene turističke destinacije. Nastavno, Buhalis (2000) ističe sljedeće strateške ciljeve marketinga turističke destinacije: osigurati lokalnom stanovništvu dugoročan napredak, maksimizirati zadovoljstvo posjetitelja, maksimizirati multiplikativne učinke i profitabilnost lokalnih poslovnih subjekata te optimizirati učinke turizma na održiv način - uz osiguranje održive ravnoteže između ekonomskih koristi te društvenih, kulturnih i aspekata okoliša, što naglašava i Skoko (2014).

\subsection{Učinci filmskog turizma}

Filmski poticaji ne utječu samo na razvoj filmske industrije već i na ostale gospodarske grane kao što su turizam i ugostiteljstvo, trgovina, obrt i poduzetništvo. Osim onih upletenih direktno u filmsku industriju, financijsku korist ostvaruju i hotelijeri, ugostitelji, iznajmljivači različitih objekata i oprema, lokalni obrti, a samim time puni se i državni proračun kroz uvećane uplate poreza na dohodak, prihode lokalnih samouprava, porez na dodanu vrijednost te ostale naknade i doprinose.

Hrvatski audiovizualni centar (2016) ističe sljedeće posredne gospodarske efekte inozemnih produkcija koji uključuju:

- dodatnu potrošnju stranih i domaćih filmskih ekipa tijekom boravka na lokacijama snimanja u Hrvatskoj izvan turističke sezone;

- povećanu gospodarsku aktivnost na lokalnoj razini (zapošljavanje lokalnog stanovništva, prodaja i proizvodnja);

- $\quad$ povezane državne doprinose (PDV, porez na dohodak) i prihode lokalnih samouprava;

- marketinški učinak visokobudžetnih projekata npr. serije lgra prijestolja ili filmova o Winnetouu - povećani interes turista za posjete Hrvatskoj (obilazak lokacija snimanja, tematske izložbe, prodaja specijaliziranih promotivnih artikala itd.).

Posebno značajan utjecaj imaju visokoprofitne komercijalne produkcije čiji su utjecaj istraživali Hudson \& Ritchie (2006) te autori Bolan \& Williams (2008) koji su zaključili da je u vrijeme velikog porasta industrije zabave, a u velikoj konkurenciji među turističkim destinacijama, filmska industrija značajna platforma za promociju destinacije. Postoji dosta istraživanja o utjecaju filma na stvaranje pozitivnog imidža destinacije (Schofield, 1996; Busby, Klug, 2001; Shani, Wang, Hudson, Gil, 2009; Hudson, Wang, Gil, 2011; Pike, Page 2014; Gartner, 2014; Beeton, 2016), a filmovi su izrazito značajna i korisna platforma za pozicioniranje manje poznatih destinacija (Carl, Kindom, Smith, 2007; Iwashita, 2008; Hahm, Wang, 2011) 
Jedan od najznačajnijih pozitivnih učinaka filmskog turizma je privlačenje turista u destinaciju izvan sezone (Beeton, 2001; Hahm, Wang, 2011; Beeton 2016). Filmske lokacije mogu se razgledavati tijekom cijele godine, što pozitivno utječe na problematiku sezonalnosti. Trajanje sezone velik je problem onih turističkih destinacija koje svoju ponudu temelje na sezonalnosti i ovise o vremenskim uvjetima, što se najčešće ogleda u primorskim destinacijama za vrijeme ljetne sezone i u planinskim destinacijama za vrijeme zimske sezone. lako su studije pokazale da je vrhunac interesa za filmsku destinaciju najveći odmah nakon što se film plasira na male ekrane, Riley et al. (1998) dokazali su da se vrhunac interesa zbiva nakon 5 godina od puštanja filma na male ekrane. Točnije, govore o dvanaest filmova nakon kojih su destinacije u kojima su filmovi snimani „oživjele“. Istraživanja na području Velike Britanije pokazala su da svaki šesti turist koji dolazi izvan zemlje posjeti barem jednu filmsku lokaciju na području Velike Britanije, a da 80 \% Britanaca planira svoje turističko putovanje nakon gledanja filma (Busby, Klug, 2001; Jewell, McKinnon, 2008; Frost, 2009; O'Connor, Flanangan, Gilbert, 2010).

Postoji, međutim, i niz negativnih učinaka filmskog turizma (Carl, Kindom, Smith, 2007; Iwashita, 2008; Frost, 2009; Hahm, Wang, 2011). Budući da se film duboko pozicionira u svijest gledatelja, pitanje je na koji će se način u njihovu svijest pozicionirati destinacija. Postoji mogućnost da se kod gledatelja pojavi negativna asocijacija na određenu destinaciju ako je na tom mjestu prikazana nedolična scena ili nekakva negativna radnja koju gledatelji mogu percipirati izričito kao nešto loše. Drugi negativan aspekt filmskog turizma ogleda se u nosivosti kapaciteta određene destinacije. Nerijetko su to mala mjesta koja ne mogu primiti velik broj posjetitelja. Tako dolazi do neželjenih posljedica kao što je zagađenje okoliša. Veliki broj posjetitelja ujedno narušava privatnost lokalnog stanovništva koje je iznimno važno u stvaranju pozitivne slike turističke destinacije (Tooke, Baker, 1996). Destrukcija prirodnog okoliša je još jedna u nizu negativnosti. Npr. snimanje filma "The Beach" rezultiralo je devastiranjem prirodnih ljepota na otoku Phi Phi Lae na jugu Tajlanda. Još jedan problem ogleda se u prikazivanju destinacije onakvom kakva ona nije u stvarnosti, što dovodi do nezadovoljstva turista prilikom njihovog posjeta (Beeton, 20016).

Iz svega navedenog nameću se još brojna pitanja oko utjecaja filmskog sadržaja na odluku pojedinca u odabiru sljedeće destinacije svog putovanja. Imaju li pojedinci među mlađom populacijom želju posjetiti neku od destinacija viđenu $u$ filmu? Što je presudno $u$ odabiru destinacije prikazane $u$ filmu? Je li to filmska priča, slavni glumci, promotivna kampanja ili pak nešto drugo?

\section{EMPIRIJSKO ISTRAŽIVANJE}

S ciljem dokazivanja postavljenih hipoteza provedeno je primarno kvantitativno empirijsko istraživanje kojim se nastojao steći uvid u poticaje koji pridonose donošenju odluke prilikom odabira turističke destinacije i povezanost odluke ispitanika pri odabiru turističke destinacije $i$ prethodnog videnja destinacije u filmu.

\section{1 Metodologija}

Podaci su prikupljeni on-line upitnikom kreiranom korištenjem Google Docs obrasca, čiji je link objavljen na društvenoj mreži Facebook u periodu od 26. travnja do 12. svibnja 2017. godine. 


\section{Bagarić, A. Jelić, D. Meštrović: Filmska industrija kao promotor turističke destinacije za mlađu... Zbornik Veleučilišta u Rijeci, Vol. 6 (2018), No.1, pp. 113-126}

Sudjelovanje u istraživanju bilo je u potpunosti anonimno i dobrovoljno. Upitnik se sastojao od 23 pitanja kojima su prikupljeni sociodemografski podaci ispitanika, podaci o navikama gledanja filmova, navikama i preferencijama ispitanika tijekom putovanja, željama i potrebama ispitanika koje se ogledaju prilikom izbora turističke destinacije viđene u filmu, podaci o već ostvarenim putovanjima u svrhu posjeta filmskim destinacijama i događajima te podaci koji se odnose na želje i buduće namjere ispitanika prilikom odabira njihove sljedeće turističke destinacije. Ispitanici su na pitanja odgovarali odabirom jednog mogućeg ponuđenog odgovora, višestrukim odabirom ponuđenih odgovora, kratkim odgovorom na otvorena pitanja te odabirom ponuđenog odgovora izraženog Likertovom skalom u rasponu od 1 - u potpunosti se ne slažem do 5 - u potpunosti se slažem. Prikupljeni podaci analizirani su primjenom metoda deskriptivne i induktivne statistike, hipoteze su testirane i doneseni su zaključci o povezanosti primjenom izračuna hi-kvadrat testa.

\section{2 Sociodemografski profil ispitanika}

Istraživanju se odazvalo 105 ispitanika, stoga taj broj predstavlja uzorak istraživanja. Za potrebe opisa uzorka ispitivanja korištena je metoda deskriptivne statistike. Sociodemografski profil ispitanika sagledao se kroz varijable spola ispitanika, njihove dobne strukture, stupnja obrazovanja i njihovog radnog statusa, kao što je prikazano tablicom 1.

Tablica 1. Sociodemografske karakteristike ispitanika

\begin{tabular}{|c|c|c|c|}
\hline \multicolumn{2}{|r|}{ Sociodemografski podaci } & Broj & Udio (\%) \\
\hline \multirow[t]{5}{*}{ Starosna dob } & $<18$ godina & 1 & 0,95 \\
\hline & $18-25$ & 93 & 88,57 \\
\hline & $26-30$ & 9 & 8,57 \\
\hline & $31-39$ & 1 & 0,95 \\
\hline & 40 i više & 1 & 0,95 \\
\hline \multirow{2}{*}{ Spol } & Muško & 18 & 17,14 \\
\hline & Žensko & 87 & 82,86 \\
\hline \multirow[t]{6}{*}{ Stupanj obrazovanja } & Osnovna škola & 1 & 0,95 \\
\hline & Srednja škola (SSS, KV) & 43 & 40,95 \\
\hline & Viša stručna sprema - VŠs (bacc.) & 52 & 49,52 \\
\hline & Visoka stručna sprema - VSS (mag.) & 9 & 8,57 \\
\hline & Znanstveni magisterij (mr. sc.) & 0 & 0,00 \\
\hline & Doktorat znanosti (dr. sc.) & 0 & 0,00 \\
\hline \multirow[t]{4}{*}{ Radni status } & Učenik & 2 & 1,90 \\
\hline & Student & 92 & 87,62 \\
\hline & Zaposlen & 8 & 7,62 \\
\hline & Nezaposlen & 3 & 2,86 \\
\hline
\end{tabular}

Izvor: izrada autora 


\section{REZULTATII DISKUSIJA}

Za analizu rezultata provedenog istraživanja kojim se nastojalo istražiti povezanost gledanja filmova s ponašanjem posjetitelja prilikom odabira turističke destinacije i steći uvid u poticaje koji pridonose donošenju odluke prilikom odabira turističke destinacije. Primijenjene su metode deskriptivne i induktivne statistike, testirane su postavljene hipoteze te doneseni zaključci o povezanosti primjenom izračuna hi-kvadrat testa.

Svih 105 ispitanika potvrdno je odgovorilo na pitanje gledaju li filmove. Na pitanje koliko često gledaju filmove, 42,9\% ispitanika odgovorilo je da gleda filmove 5 ili više puta mjesečno. Više puta tjedno filmove gleda gotovo trećina ispitanika (31,4 \%), dok više puta mjesečno filmove gleda $15,2 \%$ ispitanika. Najmanji udio ispitanika odgovorilo je da gleda filmove jednom u 2 ili 3 mjeseca (4,8 \%), odnosno svakodnevno (5,7\%). Gotovo polovica ispitanika najmanje jednom godišnje putuje iz zabave $(44,76 \%)$, dok je odabir svake sljedeće ponuđene opcije s većom učestalosti putovanja iz zabave bio sve slabije zastupljen, pa 27,62 \% ispitanika više puta godišnje putuje iz zabave, 20,95 \% putuje jednom mjesečno, a 6,67 \% putuje iz zabave jednom tjedno.

\section{1 Povezanost gledanja filmova s odlukom o odabiru turističke destinacije}

$\mathrm{U}$ svrhu testiranja prve hipoteze $\mathrm{H} 1$ : Filmovi utječu na odluku posjetitelja prilikom odabira turističke destinacije provjerilo se postojanje povezanosti gledanja filmova s odlukom o odabiru turističke destinacije. Provedeni su hi-kvadrat $\left(\chi^{2}\right)$ testovi kojima se provjerava postojanje statistički značajne povezanosti između učestalosti gledanja filmova $s$ dvjema različitim mjerama odabira turističke destinacije. Kao mjere odabira turističke destinacije odabrana su sljedeća pitanja: Želite li otputovati u neku od destinacija koje ste vidjeli u filmu? i Namjeravate li u budućnosti zaista posjetiti neku od destinacija koje ste vidjeli na filmu?.

Nastavno, u svrhu testiranja hipoteze kojom se pretpostavlja da su želje i namjere za putovanjem u destinaciju viđenu u filmu znatno veća kod ispitanika koji češće gledaju filmove, postavljene su dvije pomoćne hipoteze H1a: Postoji statistički značajna razlika između učestalosti gledanja filmova ispitanika i njihove želje za putovanjem u destinaciju koju su vidjeli u filmu i H1b: Postoji statistički značajna razlika između učestalosti gledanja filmova ispitanika i njihove namjere putovanja u destinaciju koju su vidjeli u filmu. Tablicom 2 daje se prikaz rezultata provedene analize u svrhu testirana prve pomoćne hipoteze $\mathrm{H} 1 \mathrm{a}$ koja glasi: Postoji statistički značajna razlika između učestalosti gledanja filmova ispitanika i njihove želje za putovanjem u destinaciju koju su vidjeli u filmu. 
Tablica 2. Učestalost gledanja filmova i želja za putovanjem u destinaciju viđenu u filmu

\begin{tabular}{|c|c|c|c|c|}
\hline Učestalost gledanja filmova & & $\begin{array}{c}\text { Żeli } \\
\text { otputovati }\end{array}$ & $\begin{array}{c}\text { Ne želi } \\
\text { otputovati }\end{array}$ & $\begin{array}{c}\text { Ukupno } \\
\text { Frekvencije }\end{array}$ \\
\hline \multirow[t]{4}{*}{ Svaki dan } & Frekvencije & 6 & 0 & \multirow{4}{*}{6} \\
\hline & Očekivane frekvencije & 5,3 & 0,7 & \\
\hline & Postotak & $100,0 \%$ & $0,0 \%$ & \\
\hline & Prilagođeni reziduali & 0,9 & $-0,9$ & \\
\hline \multirow[t]{4}{*}{ Više puta u tjednu } & Frekvencije & 32 & 1 & \multirow{4}{*}{33} \\
\hline & Očekivane frekvencije & 28,9 & 4,1 & \\
\hline & Postotak & $97,0 \%$ & $3,0 \%$ & \\
\hline & Prilagođeni reziduali & 2 & -2 & \\
\hline \multirow[t]{4}{*}{5 ili više puta u mjesecu } & Frekvencije & 39 & 6 & \multirow{4}{*}{45} \\
\hline & Očekivane frekvencije & 39,4 & 5,6 & \\
\hline & Postotak & $86,7 \%$ & $13,3 \%$ & \\
\hline & Prilagođeni reziduali & $-0,3$ & 0,3 & \\
\hline \multirow[t]{4}{*}{ Jednom mjesečno } & Frekvencije & 13 & 3 & \multirow{4}{*}{16} \\
\hline & Očekivane frekvencije & 14 & 2 & \\
\hline & Postotak & $81,3 \%$ & $18,8 \%$ & \\
\hline & Prilagođeni reziduali & $-0,8$ & 0,8 & \\
\hline \multirow[t]{4}{*}{ Jednom u 2 do 3 mjeseca } & Frekvencije & 2 & 3 & \multirow{4}{*}{5} \\
\hline & Očekivane frekvencije & 4,4 & 0,6 & \\
\hline & Postotak & $40,0 \%$ & $60,0 \%$ & \\
\hline & Prilagođeni reziduali & $-3,3$ & 3,3 & \\
\hline Ukupno & Frekvencije & 92 & 13 & 105 \\
\hline
\end{tabular}

Izvor: rezultati istraživanja autora

Hi-kvadrat testom provjereno je postoji li statistički značajna razlika između učestalosti gledanja filmova i želje ispitanika da otputuju u destinaciju koju su vidjeli na filmu. S obzirom na to da je dobiveni rezultat $\chi^{2}=14,595$ za stupanj slobode 4 i $p=0,006$ veći od granične tablične vrijednosti 9,488 za stupanj slobode 4 i prag značajnosti od 0,05, prihvaća se H1a hipoteza koja glasi: Postoji statistički značajna razlika između učestalosti gledanja filmova ispitanika i njihove želje za putovanjem u destinaciju koju su vidjeli u filmu te s pogreškom $p<0,05$ i sa sigurnošću $p>95 \%$ zaključuje da postoji povezanost između učestalosti gledanja filmova ispitanika i njihove želje za putovanjem $u$ destinaciju koju su vidjeli u filmu.

Nastavno, a zbog značajnosti hi-kvadrata, u tablicu je dodan redak s prilagođenim standardiziranim rezidualima, kojima se utvrdilo u kojim podskupinama je došlo do razlike. Statistički značajna odstupanja od očekivanih vrijednosti nađena su kod ispitanika koji gledaju filmove jednom u 2 do 3 mjeseca, s time da oni statistički značajno češće nego što bi bilo očekivano po slučaju odgovaraju da ne žele posjetiti destinaciju iz filma ( $z=-3,3 / 3,3 ; p=0,001)$. Također ispitanici koji gledaju filmove više puta u tjednu statistički značajno češće nego što bi bilo očekivano po slučaju odgovaraju da žele posjetiti destinaciju iz filma $(z=-2,0 / 2,0 ; p=0,046)$. Dobivene razlike su srednje veličine efekta $(V=0,373)$. Općenito se može zaključiti da ispitanici koji češće gledaju filmove imaju izraženiju želju posjetiti destinaciju viđenu u filmu. Tablicom 3 daje se prikaz rezultata provedene 
analize u svrhu testirana druge pomoćne hipoteze $\mathrm{H} 1 \mathrm{~b}$ koja glasi: Postoji statistički značajna razlika između učestalosti gledanja filmova ispitanika i njihove namjere putovanja u destinaciju koju su vidjeli u filmu.

Tablica 3. Učestalost gledanja filmova ispitanika i namjera putovanja u destinaciju viđenu u filmu

\begin{tabular}{|c|c|c|c|c|}
\hline \multicolumn{2}{|c|}{ Učestalost gledanja filmova } & $\begin{array}{c}\text { Želi } \\
\text { otputovati }\end{array}$ & $\begin{array}{c}\text { Ne želi } \\
\text { otputovati }\end{array}$ & $\begin{array}{c}\text { Ukupno } \\
\text { Frekvencije }\end{array}$ \\
\hline \multirow[t]{4}{*}{ Svaki dan } & Frekvencije & 5 & 1 & \multirow[t]{4}{*}{$x^{2}+2$} \\
\hline & Očekivane frekvencije & 4,7 & 1,3 & \\
\hline & Postotak & $83,3 \%$ & $16,7 \%$ & \\
\hline & Prilagođeni reziduali & 0,3 & $-0,3$ & \\
\hline \multirow[t]{4}{*}{ Više puta u tjednu } & Frekvencije & 29 & 4 & \multirow{4}{*}{33} \\
\hline & Očekivane frekvencije & 25,8 & 7,2 & \\
\hline & Postotak & $87,9 \%$ & $12,1 \%$ & \\
\hline & Prilagođeni reziduali & 1,6 & $-1,6$ & \\
\hline \multirow[t]{4}{*}{5 ili više puta u mjesecu } & Frekvencije & 39 & 6 & \multirow{4}{*}{45} \\
\hline & Očekivane frekvencije & 35,1 & 9,9 & \\
\hline & Postotak & $86,7 \%$ & $13,3 \%$ & \\
\hline & Prilagođeni reziduali & 1,8 & $-1,8$ & \\
\hline \multirow[t]{4}{*}{ Jednom mjesečno } & Frekvencije & 8 & 8 & \multirow{4}{*}{16} \\
\hline & Očekivane frekvencije & 12,5 & 3,5 & \\
\hline & Postotak & $50,0 \%$ & $50,0 \%$ & \\
\hline & Prilagođeni reziduali & -3 & 3 & \\
\hline \multirow[t]{4}{*}{ Jednom u 2 do 3 mjeseca } & Frekvencije & 1 & 4 & \multirow{4}{*}{5} \\
\hline & Očekivane frekvencije & 3,9 & 1,1 & \\
\hline & Postotak & $20,0 \%$ & $80,0 \%$ & \\
\hline & Prilagođeni reziduali & $-3,2$ & 3,2 & \\
\hline Ukupno & Frekvencije & 82 & 23 & 105 \\
\hline
\end{tabular}

Izvor: rezultati istraživanja autora

Hi-kvadrat testom provjereno je postoji li statistički značajna razlika između učestalosti gledanja filmova i namjere ispitanika da otputuju u destinaciju koju su vidjeli na filmu. S obzirom na to da je dobiveni rezultat $\chi^{2}(4)=21,123$ uz $p<0,001$ veći od granične tablične vrijednosti 9,488 za stupanj slobode 4 i prag značajnosti od 0,05 , prihvaća se druga pomoćna hipoteza H1b koja glasi: Postoji statistički značajna razlika između učestalosti gledanja filmova ispitanika i njihove namjere putovanja u destinaciju koju su vidjeli u filmu te s pogreškom $p<0,05$ i sa sigurnošću $\mathrm{P}>95 \%$ zaključuje da postoji povezanost između učestalosti gledanja filmova ispitanika i njihove namjere putovanja u destinaciju koju su vidjeli u filmu.

Zbog značajnosti vrijednosti hi-kvadrata u tablicu 3 dodan je redak s prilagođenim standardiziranim rezidualima kojima se utvrdilo u kojim podskupinama je došlo do razlike. Statistički značajna odstupanja od očekivanih vrijednosti nađena su kod ispitanika koji gledaju filmove jednom u 2 do 3 mjeseca, s time da oni statistički značajno češće nego što bi bilo očekivano po slučaju odgovaraju da ne namjeravaju zaista posjetiti destinaciju iz filma 
$(z=-3,2 / 3,2 ; p=0,001)$. Ispitanici koji gledaju filmove jednom mjesečno također statistički značajno češće nego što bi bilo očekivano po slučaju odgovaraju da ne namjeravaju zaista posjetiti destinaciju iz filma $(z=-3,0 / 3,0 ; p=0,003)$. Za ispitanike koji češće gledaju filmove trend se mijenja tako da oni češće zaista namjeravaju otputovati, iako efekt nije značajan (bio bi značajan uz razinu rizika od $10 \%$ za ispitanike koji gledaju filmove 5 ili više puta u mjesecu te za one koji ih gledaju više puta u tjednu). Dobivene razlike su srednje veličine efekta $(V=0,449)$. Općenito se može zaključiti da ispitanici koji češće gledaju filmove imaju izraženiju namjeru posjetiti destinacije iz filmova. Slijedom navedenog potvrđuje se hipoteza $\mathrm{H} 1$ da filmovi utječu na odluku posjetitelja prilikom odabira turističke destinacije.

\section{2 Poticaji odluci za posjet destinaciji iz filma}

Na pitanje Jeste li čuli za filmski turizam? 61 ispitanika odgovorilo je potvrdno, dok je negativno odgovorilo $39 \%$ ispitanika. Od destinacija koje su vidjeli na filmovima najviše ispitanika voljelo bi otputovati u Novi Zeland (14,3\%), u SAD-om bi išao samo jedan ispitanik manje (13,3\%). Nadalje, atraktivne filmske destinacije su Italija (9,5 \%), Japan (7,6 $\%)$, Irska (6,7 \%), Grčka (5,7 \%) i Francuska (4,8 \%).

Na pitanje jesu li ikada posjetili filmski set, samo 23,8 \% ispitanika odgovorilo je potvrdno, a 76,2 \% odgovorilo je negativno, dok je više od polovice ispitanika (56,2 \%) posjetilo neku od lokacija viđenih u filmu. Samo 6,7 \% ispitanika otišlo je na neku filmsku turu, 43,8 \% prisustvovalo je premijernom prikazivanju filma, dok većina (56,2\%) to nikada nije učinila. Gotovo trećina ispitanika (28,6 \%) otputovala je u turističku destinaciju viđenu u filmu, među kojima se ističu Italija, Hrvatska i Francuska. Kao poticaj za putovanjem istakli su se filmovi iz serijala Harry Potter i lgra prijestolja.

Čak 87,6 \% ispitanika želi otputovati u neku od destinacija viđenih u filmu, od kojih bi najveći broj (12,09 \%) željelo posjetiti Novi Zeland, slijedi Japan (11,8 \%), SAD (10,6 \%), Engleska (9,4 \%), Irska (5,9\%), Australija (4,7 \%), Italija (4,7 \%) i Rusija (4,7 \%). Od specifičnih lokacija najviše su spominjani London (5,9\%), New York (3,5\%) te lokacije na kojima su snimani filmovi o Harryju Potteru (3,5\%). Čak 15,3\% ispitanika navelo je neku drugu zemlju koju bi voljeli posjetiti, a koja nije bila navedena među ponuđenim destinacijama viđenim u filmu. Tu spadaju: Bora Bora, Egipat, Fiji, Indija, Izrael, Karibi, Kuba, Lima, Malta, Maroko, Norveška, Škotska i Tajland. Na pitanje Namjeravate li u budućnosti zaista posjetiti neku od destinacija koje ste vidjeli u filmu? 78,1 \% ispitanika odgovorilo je potvrdno, od kojih najveći broj zaista namjerava otputovati u Japan (11,7 \%), Italiju (10,4 \%), Englesku (9,15\%), SAD (9,1 \%), Irsku (7,8 \%), Novi Zeland (7,8 \%) i Francusku (6,5\%).

U svrhu stjecanja uvida u poticaje s najvišim doprinosom donošenju odluke za posjet destinaciji prikazanoj u filmu, izračunate su prosječne ocjene za različite poticaje. Viša ocjena predstavljala je veću privlačnost poticaja, raspon ocjena kretao se od 1 do 5 , a rezultati analize prikupljenih podataka prikazani su u tablici koja slijedi. 
Tablica 4. Doprinos poticaju odluci za posjet destinaciji iz filma

\begin{tabular}{|lcc|}
\hline Poticaj odluci za posjet destinaciji iz filma & M & SD \\
\hline Ljepote krajolika & 4,34 & 1,19 \\
\hline Specifične lokacije iz filma & 4,00 & 1,19 \\
\hline Kulturno-povijesne znamenitosti & 3,91 & 1,10 \\
\hline Scenografija & 3,49 & 1,24 \\
\hline Način života prikazan u filmu & 3,44 & 1,47 \\
\hline Filmska priča & 3,14 & 1,30 \\
\hline Marketinška kampanja & 2,90 & 1,10 \\
\hline Glumci & 2,76 & 1,27 \\
\hline
\end{tabular}

Napomena: $M$ - aritmetička sredina, SD - standardna devijacija

$$
\text { Izvor: izrada autora }
$$

Kao najveći poticaj donošenju odluke prilikom odabira turističke destinacije pokazale su se Ljepote krajolika ( $M=4,34$; SD = 1,19), zatim Specifične lokacije $(M=4,00 ; S D=1,19)$ i Kulturno-povijesne znamenitosti $(M=3,91 ; S D=1,10)$. Kao slabiji poticaj istakli su se Filmska priča $(M=3,14 ; S D=1,30)$, Marketinška kampanja $(M=2,90 ; S D=1,10)$ te Glumci $(M=2,76 ; S D=1,27)$.

S obzirom na to da je poticaj Filmska priča rezultirao ocjenom aritmetičke sredine 3,14 i u odnosu na poticaj Ljepota krajolika, koji je ocijenjen aritmetičkom sredinom 4,34 i Specifične lokacije iz filma s ocjenom 4,00 te ostalim poticajima koji su ocijenjeni višom ocjenom, što je vidljivo iz tablice 4, druga hipoteza da je filmska priča presudna u odabiru destinacije prikazane u filmu djelomično je prihvaćena i zaključuje se da filmska priča jest poticaj, ali nije presudna za odabir turističke destinacije.

\section{3 Ograničenja i smjernice budućih istraživanja}

Ovo istraživanje provedeno je na prigodnom uzorku ispitanika mlađe populacije koja najčešće nema vlastite prihode, a sredstva za moguća putovanja po vlastitom izboru vrlo su ograničena, stoga interpretaciju rezultata treba uzeti u obzir s oprezom. Autori smatraju da je u budućnosti potrebno posvetiti veću pozornost istraživanjima o utjecaju filmske industrije na odluke o odabiru turističke destinacije i na ostale aspekte filmskog turizma, koja će obuhvatiti veći broj čimbenika koji pridonose odluci o odabiru filmske turističke destinacije koji ovim istraživanjem nisu obuhvaćeni. S ciljem omogućavanja generalizacije rezultata, autori sugeriraju replikaciju istraživanja na uzorku ispitanika opće populacije. S obzirom na porast broja međunarodnih filmskih produkcija tijekom posljednjih godina filmski turizam u Hrvatskoj bilježi značajan porast pa rezultati ovog istraživanja mogu poslužiti kao putokaz za planiranje marketinških aktivnosti i brendiranje Hrvatske kao filmske destinacije. 


\section{ZAKLJUČAK}

Film ima snažnu ulogu u promociji turističke destinacije budući da je u njega satkan audio-vizualni sadržaj.Upravo zbog toga slakoćom možeprikazati destinacijuna najpoželjniji način. Filmski turizam identificira optimalne marketinške faktore kojima se potiču filmski turisti da posjete odredišta koja se pojavljuju u filmovima. Filmovi i ostali popularni mediji prenose bitne informacije o mjestu u kratkom vremenskom razdoblju, stoga publika smatra informacije distribuirane kroz takve kanale kao relevantne, objektivne i nepristrane u usporedbi s konvencionalnim oglašavanjem. Budući da velik broj destinacija nema dovoljno novca za ulaganje u dugoročne marketinške kampanje filmski inducirani turizam javlja se kao najpoželjnije i najučinkovitije sredstvo promocije. Jedna od najjačih prednosti filma kao promotivne aktivnosti ogleda se u tom da film nema rok trajanja te na taj način uvijek iznova može privlačiti turiste.

Temeljem dobivenih rezultata istraživanja dokazano je da je gledanje filmova povezano $s$ odlukom o odabiru turističke destinacije. Provedeno istraživanje navodi na zaključak da ljepote krajolika viđene u filmu i općenito prirodne ljepote predstavljaju najveći poticaj odluci o odabiru turističke destinacije, uz specifičnost lokacije i raznovrsnost kulturno-povijesnih znamenitosti koji se također mogu smatrati izuzetno značajnim poticajima. Nešto slabijim poticajima mogu se smatrati scenografija i način života prikazan u filmu, dok filmska priča, marketinška kampanja i glumačka postava spadaju u poticaje s manjim doprinosom odluci o odabiru turističke destinacije. Učestalost gledanja filmova povezana je s odlukom o odabiru turističke destinacije, pa ispitanici koji češće gledaju filmove imaju izraženiju želju i stvarnu namjeru posjetiti destinacije viđene u filmovima. Financijski poticaji za filmske i televizijske produkcije posljednjih godina rezultirali su procvatom filmskog turizma u Hrvatskoj, što je od velikog značaja za budući razvoj hrvatskog turizma i promociju Hrvatske kao filmske turističke destinacije.

\section{LITERATURA}

Beeton, S. (2001) "Smiling for the Camera: The Influence of Film Audiences on a Budget Tourism Destination", Tourism Culture and Communication, 3(1), p. 15-25

Beeton, S. (2016) Film-Induced Tourism, Channel View Publications

Bolan, P. (2009) „Displacement Theory - Probing New Ground in Film-Induced Tourism“, dostupno na: http://www. shannoncollege.com/wp-content/uploads/2009/12/THRIC-2010-Full-Paper-P.-Bolan.pdf (22. 12. 2017.)

Bolan, P. and Williams, L. (2008) The Role of Image in Service Promotion: Focusing on the Influence of Film on Consumer Choice within Tourism, International Journal of Consumer Studies, Vol. 32, Issue 4, p. 382-390

Buhalis, D., (2000) „Marketing the competitive destination of the future“, Tourism Management, 21, p. 97-116

Busby, G. and Klug, J. (2001) Movie Induced Tourism: The Challenge of Measurement and Other Issues, Journal of Vacation Marketing, Vol. 7, Issue 4, p. 316-332

Carl, D., Kindom, S. and Smith, K. (2007), Tourist's Experiences of Film Locations: New Zeland as 'Middle Earth', Tourism and Geographies: An International Journal of Tourism Space, Vol. 9, Issue 1, p. 49-63

Evans, M. (1997) „Plugging into TV tourism“, U: Insights, London: English Tourist Board, D35-D38

Frost, W. C. (2009) From Backlot to Runway Production: Exploring Location and Authenticity in Film - Induced Tourism, Tourism Review International, Vol. 13, Issue 2, p. 85-92 
Gartner, W. C. (2014) Brand equity in a tourism destination. Place Branding and Public Diplomacy, 10(2), p. 108-116

Hahm, J. and Wang, Y. (2011) Film - Induced Tourism as a Vehicle for Destination Marketing: Is It Worth the Efforts?, Journal of Travel \& Tourism Marketing, Vol. 28, Issue 2, p. 165-179

Hrvatski audiovizualni centar (2016) „Izvještaj o radu za 2015. godinu“, dostupno na: https://www.havc.hr/file/ publication/file/havc-izvjestaj-2015-web.pdf (2. 5. 2017.)

Hudson, S. and Ritchie, J. R. B. (2006) Promoting Destinations via Film Tourism: An Empirical Identification of Supporting Marketing Initiatives, Journal of Travel Research. Vol. 44, Issue 4, p. 387-396

Hudson, S., Brent Ritchie, J. R. (2006) „Promoting Destinations via Film Tourism: An Empirical Identification of Supporting Marketing Initiatives", Journal of Travel Research, 44(4), p. 387-396

Hudson, S., Wang, Y., Gil, S. M. (2011) The Influence of a Film on Destination Image and the Desire to travel: a Cross Cultural - Comparison, International Journal of Tourism Research, Vol. 13, Issue 2, p. 177-190

Iwashita, C. (2008) Roles of Film and Television Dramas in International Tourism: The Case of Japanese Tourists to UK, Journal of Travel \& Tourism Marketing, Vol. 24, Issue 2-3, p. 139-151

Jewel, B., and McKinnon, S. (2008) Movie Tourism - A New Formo f Cultural Landscape?, Journal of Travel \& Tourism Marketing, Vol. 24, Issue 2-3, p. 153-162

Križman Pavlović, D., Živolić, S. (2008) „Upravljanje marketingom turističke destinacije: stanje i perspektive u Republici Hrvatskoj", Economic research - Ekonomska istraživanja, 21(2), p. 99-113

Macionis, N. (2004) „Understanding the Film-Induced Tourist“. U: International Tourism and Media Conference Proceedings. Melbourne: Monash University, p. 86-97

McKercher, B., Du Cros, H. (2002) Cultural tourism: The partnership between tourism and cultural heritage management, New York: Haworth Hospitality Press

Međunarodna udruga za destinacijski marketing (DMAI), Godišnje izvješće 2016, dostupno na: https://dmai.force.com/ cpbase_event_detail?id=a10370000005GpWEAUs

Morgan, N., Pritchard, A. (1998) Tourism Promotion and Power: Creating Images, Creating Identities. Chichester: John Wiley \& Sons

O'Connor, N., Flanagan, S., and Gilbert, D. (2010) The Use of Film in Re-Imaging a Tourism Destination: A Case Study of Yorkshire, UK, Journal of Vacation Marketing, Vol. 16, Issue 1, p. 61-74

Pike, S., \& Page, S. J. (2014). Destination marketing organizations and destination marketing: A narrative of the literature. Tourism Management, 4, p. 202-227.

Riley, R., D. Baker, van Doren, C. S. (1998) “Movie Induced Tourism”, Annals of Tourism Research, 25(4), p. 919-935

Schofield, P. (1996) Cinematographic Images of a City, Tourism Management, Vol. 17, Issue 5, p. 333-340

Shani, A., Wang, Y., Hudson, S. and Gil, S. M. (2009) Impacts of a Historical Film on the Destination Image of South America, Journal of Vacation Marketing, Vol. 15, Issue 3, p. 229-242

Skoko, B. (2014) „Mogućnosti i načini jačanja brenda Dubrovnika uz pomoć filmske industrije i organiziranja događaja“, Zbornik Sveučilista u Dubrovniku, (1), p. 175-191

Tooke, N., Baker, M. (1996) "Seeing is Believing: The Effect of Film on Visitor Numbers to Screened Locations", Tourism Management, 17(2), p. 87-94

Woodward, I. (2000) „Why should the UK's tourism industry be interested in 'Bollywood' films?", U: ,Insights, London: English Tourism Council, A23-A26 


\title{
FILM INDUSTRY AS A PROMOTER OF THE TOURIST DESTINATION FOR THE YOUNGER POPULATION ${ }^{4}$
}

\begin{abstract}
Film tourism is becoming more and more popular in the global tourism market and competition among host destinations is growing so great efforts are made to attract film sets. Film locations play a significant role in planning marketing activities for tourist destinations. This paper aims to explore the relationship between watching movies and consumers' behavior when choosing a tourist destination. Hypotheses have been proposed suggesting that watching movies is related to consumers' decisions when choosing a tourist destination and that a movie story is a pivotal factor when choosing a tourist destination. In order to test the proposed hypotheses, quantitative research was conducted. The respondents were asked to answer the questions related to their moviewatching habits, their travel habits and preferences, desires and needs when choosing a tourist destination that was seen in the movie, trips already made for the purpose of visiting movie events and destinations, and their desires and intentions when choosing the next tourist destination. The data were analysed using descriptive and inductive statistics, the hypotheses were tested and conclusions about the association between the examined variables were made using the Chi-square test. The results confirmed a significant association between the respondents' prevalence of watching movies and their intentions when choosing a tourist destination, but the main incentives to visit the destination are the beauty of the landscape, specific film location and cultural and historical sites. Research was carried out on a convenience sample, thus, the interpretation and generalization of the results should be treated with some caution. Given the significant increase of film tourism in Croatia over the past years, the authors recognize the results might be useful as implications for planning of marketing activities and possibilities for branding Croatia as a film destination.
\end{abstract}

Key words: film tourism, travelling motives, destination marketing, destination choice, consumer behaviour

PhD, Assistant Professor, Faculty of Tourism and Hospitality Management, Primorska 42, 51410 Opatija, Croatia. E-mail: lidijab@fthm.hr

2 M Econ, Student, Faculty of Tourism and Hospitality Management, Primorska 42, 51410 Opatija, Croatia.

3 M Econ, Centre for Studies and Students, University of Rijeka, Radmile Matejčić 2, 51000 Rijeka, Croatia. E-mail:dmestrovic@uniri.hr

4 Received: 15 January 2018; Accepted: 1 March 2018 